Post Print

This is the peer-reviewed version of the following article

Jean-Yves Wach, Barbora Malisova, Simone Bonazzi, Samuele Tosatti, Marcus

Textor, Stefan Zürcher, and Karl Gademann*

Protein-Resistant Surfaces through Mild Dopamine Surface Functionalization

Chem. Eur. J. 2008, 14, $10579-10584$

DOI: $10.1002 /$ chem.200801134

This post print was deposited at http://infoscience.epfl.ch

In compliance with the directive of the Swiss National Science Foundation 


\title{
Protein-Resistant Surfaces through Mild Dopamine Surface Functionalization
}

\author{
Jean-Yves Wach, ${ }^{[a]}$ Barbora Malisova, ${ }^{[b]}$ Simone Bonazzi, ${ }^{[a]}$ Samuele Tosatti, ${ }^{[b]}$ Marcus Textor, ${ }^{[b]}$ \\ Stefan Zürcher, ${ }^{[b]}$ and Karl Gademann**a]
}

\begin{abstract}
The synthesis and evaluation of new dopamine based catechol anchors coupled to poly(ethylene glycol) (PEG) for surface modification of $\mathrm{TiO}_{2}$ surfaces is reported. Dopamine is modified by dimethylaminemethylene (7) or trimethylammoniummethylene (8) groups, and the
\end{abstract}

resulting surfaces substantially reduced protein adsorption upon exposure to full human serum.

\section{Keywords: biofouling biomimetic strategies $\cdot$ natural products $\cdot$ surface chemistry . synthesis.}

\section{Introduction}

The non-specific attachment of macromolecules of biological nature such as proteins or of microorganisms such as bacteria or fungi to surfaces (so-called biofouling) is a fundamental problem in areas ranging from medical devices and biosensors ${ }^{[1]}$ to protein production, handling and storage. ${ }^{[2]}$ Surfaces suffer from biofouling as soon as they are exposed to biological fluids or protein solutions. This process $^{[3]}$ is often considered the first step related to nosocomial infections, ${ }^{[4]}$ a serious problem nowadays in hospital settings.

The direct approach to preventing such biofouling is the generation of antifouling surfaces, ${ }^{[5]}$ i.e. coatings that repel the adhesion of proteins and cells. Over the last years, effective antifouling polymers have been developed including poly ethylene glycol $^{[6]}$ polyglycerol, ${ }^{[7]}$ poly(ethyleneoxide)-poly(propylene-

[a] Prof. Dr. K. Gademann, J.-Y. Wach, MSc, S. Bonazzi, MSc Chemical Synthesis Laboratory (SB-ISIC-LSYNC) Swiss Federal Institute of Technology (EPFL) CH-1015 Lausanne, Switzerland Fax: (+) 41216931500 E-mail: karl.gademann@epfl.ch

[b] Prof. Dr. M. Textor, Dr. S. Tosatti, Dr. S. Zürcher, B. Malisova, MSc Laboratory for Surface Science and Technology Swiss Federal Institute of Technology (ETH) CH-8093 Zürich, Switzerland

Supporting information for this article is available on the WWW under http://www.chemeurj.org/ or from the author oxide)/pluronics, ${ }^{[8,9]}$ peptoids, ${ }^{[10]}$ poly-2-methyl-2-oxazoline ${ }^{[11]}$ and others. The remaining general challenge consists in attaching these polymers to surfaces in a mild, rapid and efficient way. Several approaches have been developed based on poly-electrolytes, ${ }^{[12]}$ silanes $^{[13]}$ or thiols ${ }^{[14]}$ on gold. All these approaches suffer from limitations regarding scope, stability or reactivity of anchoring groups. Recently, catechols have been presented as promising alternative adhesives in surface modifications. ${ }^{[15]}$ These anchors are found in mussel-adhesive proteins (MAPs) ${ }^{[16]}$ which are responsible for the very strong wet adhesion of mussels to surfaces. MAPs have been shown to contain up to $27 \%$ of the catechol dihydroxyphenylalanine (1, DOPA), which is the key constituent for adhesion. Based on early work by Waite and coworkers, ${ }^{[15 a]}$ and then Grätzel and coworkers, ${ }^{[15 b]}$ Messersmith and coworkers ${ }^{[15 c-h]}$ demonstrated the usefulness of catechols for surface functionalization. In these systems, however, oligomers of DOPA such as $\mathbf{2}$ are required to achieve sufficient adhesion stability and protein resistance. We were able to overcome this limitation by introducing the anchor $\mathbf{3}^{[17 \mathrm{a}]}$ for effective single site attachment based on the iron chelator anachelin. ${ }^{[18]}$ This biomimetic
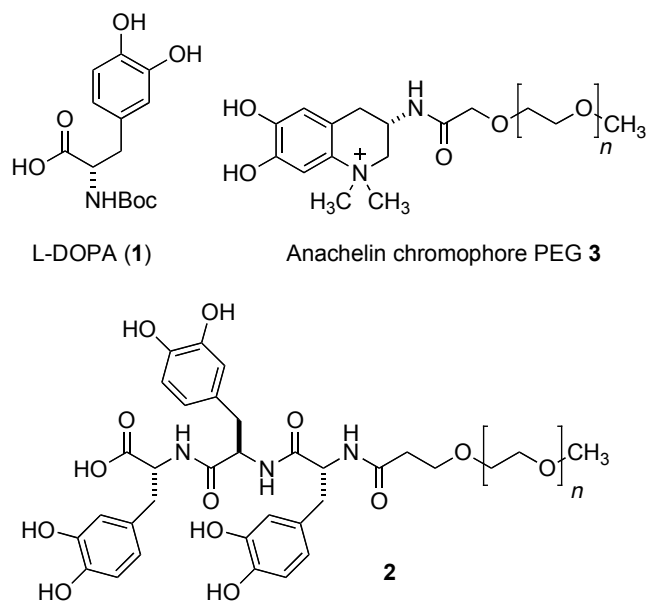
strategy allowed for the generation of PEG-based, proteinresistant ${ }^{[17 a]}$ and cell-resistant ${ }^{[17 b]}$ surfaces, with the drawback that the anchor requires multi-step organic synthesis involving heavy metal-based $^{[18 a-b]}$ or enzymatic ${ }^{[18 c-d]}$ conversions. We sought to structurally simplify this anchor, and, while retaining its benefits, making its preparation more straightforward. In this article, we present structurally simple, easy-to-produce anchors that allow for the generation of protein-resistant $\mathrm{TiO}_{2}$ surfaces through straightforward dip-and-rinse procedures.

\section{Results and Discussion}

The goal of this investigation was the design of an effective catechol surface anchor that can generate protein-resistant surfaces, and that is readily available via a short synthetic route. We initially proposed that the key to successful surface immobilization via single site attachment is the combination of both catechol and a positive ammonium group as in 3. $^{[17 a]}$ These functional units should synergistically act on surface binding - with the catechol as the anchoring group in a similar fashion to MAPs, and the positive charge inducing favorable interactions with the negatively charged surface of the metal oxide. Therefore, we turned our attention to compound 4 , which is readily available from Boc-L-DOPA. ${ }^{[18 a, b]}$ This mono-protected catechol diamine exists at physiological conditions in a charged state thus displaying the desired properties of catechol and positive charge. A permanent, $\mathrm{pH}$-independent positive charge was introduced by $\mathrm{N}$-methylation of $\mathbf{4}$ in one step with excellent yield (97\%) (Scheme 1). The resulting compound $\mathbf{5}$ can therefore be obtained through a short synthetic sequence from DOPA. In addition to the mono catechol anchors such as $\mathbf{4}$ and $\mathbf{5}$, we were interested in dicatechol anchors because of their increased adhesion stability on surfaces. ${ }^{[15 \mathrm{~g}]}$ Thus, the dicatechol-diamine $\mathbf{6}$ was prepared in two steps from $\mathbf{4}$, simply via deprotection of $\mathbf{4}$ and coupling to Boc-L-DOPA. The three anchors 4-6 were deprotected, and coupled to poly(ethylene glycol) (PEG-5000) via the corresponding PEG-succinidyl esters and purified by size exclusion chromatography. The resulting polymers 7-9 were thus readily available for surface functionalization.
Scheme 1. Preparation of catechol-PEG conjugates for surface modification: a) $\mathrm{Boc}_{2} \mathrm{O}$,<smiles>C[C@H](N[C@@H](Cc1ccc(O)c(O)c1)CN(C)C)C(=O)OC(C)(C)C(=O)O</smiles>

5<smiles>CN(C)C[C@H](Cc1ccc(O)c(O)c1)NC(=O)[C@H](Cc1ccc(O)c(O)c1)NC(=O)OCc1ccccc1</smiles>

4

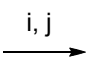<smiles>COCCOCCC(=O)N[C@@H](Cc1ccc(O)c(O)c1)CN(C)C</smiles>

5
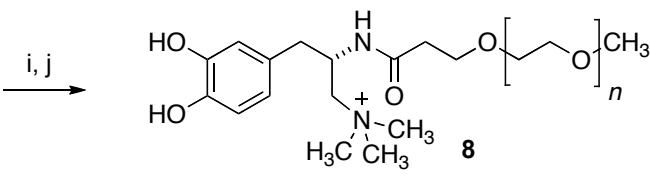
$\mathrm{OH}$<smiles>CCOCCOCCC(=O)N[C@@H](Cc1ccc(O)c(O)c1)C(=O)N[C@H](Cc1ccc(O)c(O)c1)CN(C)C</smiles>

$\mathrm{NaOH}$ (aq.), dioxane, RT, $16 \mathrm{~h}$; b) i. $i$-BuOCOCl, THF, $-35^{\circ} \mathrm{C}, 0.5 \mathrm{~h}$; ii. $\mathrm{HNMe}_{2}, \mathrm{THF}$, $35^{\circ} \mathrm{C}$ to RT, $16 \mathrm{~h}, 68 \%$ (over 3 steps); c) $\mathrm{Cs}_{2} \mathrm{CO}_{3}, \mathrm{BnBr}$, acetone, reflux, $4 \mathrm{~h}, 83 \%$; d) i. TFA, $\mathrm{CH}_{2} \mathrm{Cl}_{2}, 0^{\circ} \mathrm{C}, 1 \mathrm{~h}$; ii. $\mathrm{BH}_{3} \cdot \mathrm{THF}, \mathrm{THF}, 0^{\circ} \mathrm{C}$ to RT, $16 \mathrm{~h}$; iii. $\mathrm{Boc}_{2} \mathrm{O}, \mathrm{NaOH}$ (aq.), dioxane, RT, 16h, 53\% (over 3 steps); e) $\mathrm{H}_{2}, \mathrm{Pd} / \mathrm{C}, \mathrm{AcOH}, \mathrm{MeOH}, 14 \mathrm{~h}, \mathrm{RT}, 99 \%$; ) $\mathrm{CH}_{3} \mathrm{I}, \mathrm{CH}_{2} \mathrm{Cl}_{2} / \mathrm{MeOH}(2: 1)$, 6h, RT; g) TFA, $\mathrm{CH}_{2} \mathrm{Cl}_{2}, 0^{\circ} \mathrm{C}, 1 \mathrm{~h}$; h) Boc-L-DOPA, $\mathrm{NEt}_{3}$, HOBt, EDC, 14h, RT, 54\% (over 2 steps); i) $\mathrm{HCl}(4 \mathrm{M})$ in dioxane, dioxane, $0^{\circ} \mathrm{C}, 2 \mathrm{~h} ; \mathrm{j}$ ) mPEG-SPA, NMM, $\mathrm{CH}_{2} \mathrm{Cl}_{2} / \mathrm{DMF}$ (1:1), RT, $64 \%$ (for 7), $44 \%$ (for 8 ), $60 \%$ (for 9).

In addition, we prepared the didopamine polymer $\mathbf{1 1}$ in three steps from Boc-L-Glu (10), via coupling to dopamine, deprotection and pegylation with mPEG succinidyl ester (Scheme 2). This compound $\mathbf{1 1}$ was designed in view of beneficial properties through bidentate anchoring of the catechols on the surface, while being readily available through a short 3 step synthetic sequence. From a mechanisitc point of view, this compound could also allow for the investigation of the role of the amino group in 9 with respect to two catechol units. Compound $\mathbf{1 1}$ should also display increased binding properties, when compared to dopamine PEG polymer 12, as noted earlier for DOPA based polymers. ${ }^{[10,15 \mathrm{~g}]}$ 
<smiles>COC(C)(C)COC(C)(C)CCC(=O)NC(CCC(=O)NCCc1ccc(O)c(O)c1)C(=O)NCCc1ccc(O)c(O)c1</smiles><smiles>COC(C)(C)COC(C)(C)CC(=O)NCCc1ccc(O)c(O)c1</smiles>

12

Scheme 2. Preparation of mPEG didopamine polymer 11: a) Dopamine hydrochloride, $\mathrm{NEt}_{3}, \mathrm{HOBt}, \mathrm{EDC}, 14 \mathrm{~h}, \mathrm{RT}, \mathrm{CHCl}_{3}$; b) $\mathrm{HCl}(4 \mathrm{M})$ in dioxane, dioxane, $0^{\circ} \mathrm{C}, 2 \mathrm{~h}$; c) mPEG-SPA, NMM, $\mathrm{CH}_{2} \mathrm{Cl}_{2}$ /DMF (1:1), RT, $58 \%$.

The generation of protein-resistant surfaces was then carried out by means of spontaneous adsorption (self assembly) using a dipand-rinse protocol. As surface, $\mathrm{TiO}_{2}$ was chosen in view of its relevance for the field of biomedical implants and biosensors. ${ }^{[19]}$ Thus, clean $\mathrm{TiO}_{2}$ surfaces were dipped in dilute solutions of 7-9 and 11-12 $\left(0.1 \mathrm{mg} \mathrm{ml}^{-1}\right.$ of polymers in high salt buffer $(0.1 \mathrm{M} \mathrm{MOPS} / 0.6$ $\left.\mathrm{M} \mathrm{NaCl} / 0.6 \mathrm{M} \mathrm{K}_{2} \mathrm{SO}_{4}\right)$ ) for $4 \mathrm{~h}$ at $50{ }^{\circ} \mathrm{C}$. These 'cloud point' conditions were chosen to achieve dense packing of $\mathrm{PEG}$ and thus maximize PEG surface density. ${ }^{[5]}$ After incubation, the resulting surfaces were shortly rinsed with water, and the thickness of the adlayer was measured by variable angle spectroscopic ellipsometry (VASE). This measured thickness is proportional to the amount of polymer adsorbed and thus directly reflects the mass of PEG on the surface. From these values (Figure 1, circles), it is evident that polymer $\mathbf{8}$ featuring the quaternary ammonium anchor as well as the didopamine polymer $\mathbf{1 1}$ displayed the highest mass adsorbed. Among the monocatechol polymers, the performance of $\mathbf{8}$ is comparable to the anachelin chromophore polymer $\mathbf{3}$ and to the one measured for dopamine derived 12. Clearly, the non-permanently charged polymer 7 displayed a lower adlayer thickness. As a next step, the polymers were equilibrated by exposing the surfaces to physiological buffer (HEPES 2; pH 7.4) for $24 \mathrm{~h}$. At the same time, the PEG chains become rehydrated in this process. Adlayer thickness of all polymers was again measured by VASE (Figure 1, squares). The quaternary ammonium polymer $\mathbf{8}$ again displayed a high value, with a measured thickness of roughly $17 \AA$. This is comparable to control polymer $\mathbf{3}$, and to dopamine derived $\mathbf{1 2}$. The tertiary amine polymer 7 showed a significantly lower thickness, with a measured value of $9.8 \AA$.

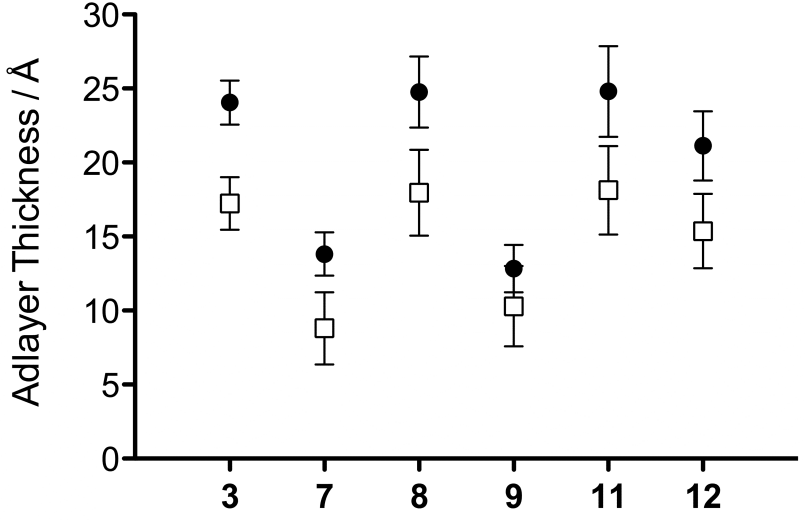

Figure 1. Adlayer thickness of polymers 3 (8), 7 (10), 8 (9), $9(10), 11(6)$ and 12 (8) as measured by VASE (numbers in parentheses refer to number of independent experiments, error bars denote the standard deviation). Filled circless correspond to the values measured directly after adsorption in cloud point buffer, empty squares correspond to values measured after equilibration in physiological buffer at $\mathrm{pH}$ 7.4.

We next investigated the adlayer thickness of divalent didopamine derivatives $\mathbf{9}$ and $\mathbf{1 1}$ (Figure 1). Interestingly, the derivative $\mathbf{9}$ featuring additional amino groups displayed similar low initial adlayer thickness when compared to the parent monovalent polymer 7, and, after $24 \mathrm{~h}$ exposure to buffer, adlayer thickness of $8.8 \AA$ was determined. The divalent dopamine derivative 11, however, gave the highest adlayer thickness, both after adsorption (ca. $25 \AA$ ) and after $24 \mathrm{~h}$ incubation in buffer (ca. $18 \AA$ ).

From these data, the following conclusions can be drawn: (1) A permanent positive charge, present for example in $\mathbf{8}$, results in higher values for the adlayer thickness (on negatively charged surfaces), and therefore higher adsorbed mass for the monovalent compounds. Thus, polymers such as $\mathbf{8}$ and the control $\mathbf{3}$ have superior adsorption properties when compared to non-permanently charged aminodopamines such as 7. (2) The didopamine polymer 11 resulted in the highest adlayer thickness as determined by VASE. Clearly, an optimal arrangement of both catechols is beneficial for surface attachment. In contrast, the diamino dopamine polymer 9 performed poorly, with layer thicknesses similar to its monovalent counterpart 7. Increased steric hindrance expected for molecule 9 when compared to $\mathbf{1 1}$ is possibly the reason for the observed lower adlayer thickness. Molecular modelling supports this view, where the dimethylamino group in $\mathbf{9}$ appears to spatially separate the catechol units and thus preventing multivalent attachment (data not shown). From the adsorption data after incubation for $24 \mathrm{~h}$ under physiological conditions, it can be concluded that the performance regarding adlayer thickness of the group of polymers $3,8,11$, and $\mathbf{1 2}$ are superior to 7 and $\mathbf{9}$. 


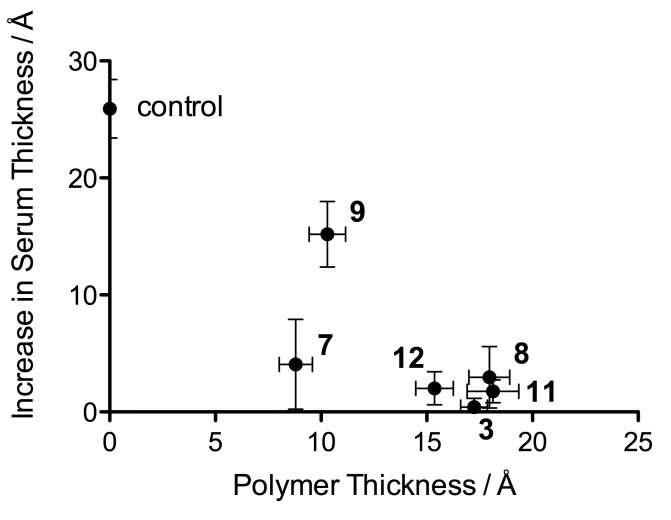

Figure 2. Measured increase in layer thickness due to serum adsorption on polymer adlayers of 3, 7, 8, 9, 11 and 12 plotted vs. polymer adlayer thickness after equilibration for $24 \mathrm{~h}$ in physiological buffer. "Control" refers to the bare $\mathrm{TiO}_{2}$ surface.

Next, we investigated the protein adsorption to the $\mathrm{TiO}_{2}$ surfaces coated with the different polymers as prepared above. The resulting surfaces were subsequently exposed to human serum for 20 minutes, rinsed with buffer and ultra-pure water and the resulting increase in layer thickness was measured by VASE (Figure 2). These results demonstrate that coatings of $\mathbf{7}$ and $\mathbf{8}$ substantially reduce non-specific serum adsorption when compared to bare $\mathrm{TiO}_{2}$ (Figure 2, control). The measured protein resistance values for 7 and $\mathbf{8}$ are slightly lower when compared to the anachelin chromophore 3, reflecting their lower polymer adlayer thicknesses (Figure 1). In addition, while the introduction of a permanent charge such as in $\mathbf{8}$ leads to increased PEG surface coverage as judged by VASE (Figure 1), it has no influence on the protein resistance (Figure 2), as both polymers $\mathbf{7}$ and $\mathbf{8}$ are equally efficient towards this goal.

Surprisingly, the diamino catechol polymer 9 coating was inefficient in reducing protein-adsorbed mass (Figure 2), in contrast to the expectation given the adlayer thickness of $10 \AA$ after buffer incubation (Figure 1). The reason for this unexpected result is unclear at present. A significantly better performance in this respect showed didopamine polymer 11, with over $95 \%$ reduction of protein adsorption when compared to the control. This polymer $\mathbf{1 1}$ as well as the charged monovalent $\mathbf{8}$ thus display with regard to performance in adlayer thickness and protein resistance generally the best values.

The data obtained from VASE experiments were further corroborated by X-ray photoelectron spectroscopy (XPS) measurements. For protein-resistant surfaces, the chemical composition of the adsorbate layer is expected to remain unchanged while surfaces that adsorb proteins should show a substantial increase in the surface nitrogen concentration as well as changes in the composition of the carbon components of the C1s signal. The XPS data confirmed that surfaces identified by VASE as protein resistant, e.g. 3, 11 and 12, also show the smallest change in their chemical composition (shown in supporting information). The combined XPS and VASE findings for these three polymers clearly demonstrate that the measured layer thickness after the serum test mostly reflects the polymer film and that adsorption or exchange of polymer molecules by proteins has not taken place to a significant degree. In contrast, the films obtained from 7 and 9 show a substantial increase in the nitrogen as well as carbon surface concentration. The XPS data also demonstrate, that thicker polymer layers (corresponding to a higher $\mathrm{C} / \mathrm{Ti}$ atomic concentration ratio) with correspondingly higher PEG chain surface density result in more favorable protein resistance which is in agreement with the ellipsometry data (Figure 2).

\section{Conclusion}

In conclusion, we presented the synthesis and evaluation of a series of new dopamine based anchors for surface functionalization. Two anchors with excellent properties were identified: dopamine $\mathbf{8}$ with a permanent positive charge displayed comparable adlayer thickness when compared to the reference 3 . The didopamine polymer $\mathbf{1 1}$ was identified as the anchor of choice, as this compound showed the highest adlayer thickness while displaying a large reduction of protein attachment. In addition, the didopamine anchor of 11 can be prepared from Boc-L-Glu and dopamine in a straightforward and convenient one-step process. Benefits of the new anchors included in $\mathbf{8}$ and $\mathbf{1 1}$ are: (1) Ease of synthesis when compared to formerly reported systems such as $\mathbf{3}$, (2) operationally simple dip-and-rinse protocols for the generation of protein-resistant surfaces, and (3) mild surface functionalization through catechols, which are compatible with many functional groups. Applications of the novel surface-active molecules for the generation of functional surfaces are currently underway in our laboratories.

\section{Experimental Section}

Materials and Methods: Chemicals were purchased from Fluka, ABCR or Acros and used without further purification. Analytical thin layer chromatography (TLC) was performed on Merck silica gel $60 \mathrm{~F} 254$ plates $(0.25 \mathrm{~mm}$ thickness $)$ precoated with a fluorescent indicator. The developed plates were examined under UV light and stained with ceric ammonium molybdate followed by heating. All ${ }^{1} \mathrm{H}$ and ${ }^{13} \mathrm{C}$ NMR spectra were recorded using a Bruker DPX $400 \mathrm{MHz}\left({ }^{1} \mathrm{H}\right)$ or $100 \mathrm{MHz}\left({ }^{13} \mathrm{C}\right)$ FT spectrometer at $\mathrm{RT}$, chemical shift $\delta$ given in ppm and coupling constant $J$ in Hz. IR spectra were recorded using a Varian 800 FT-IR ATR Spectrometer. The absorptions are reported in $\mathrm{cm}^{-1}$ and the IR bands were assigned as $s$ (strong), $m$ (medium) or $w$ (weak). All mass spectra were recorded by the Mass Spectroscopy service of EPF Lausanne on MICROMASS (ESI) Q-TOF Ultima API. Melting points were determined using a Büchi B-545 apparatus in open capillaries and are uncorrected. Compound 4 was prepared according to the literature, ${ }^{[18]}$ and procedures and data are reported in the supporting information.

$\mathrm{TiO}_{2}$ Surfaces and surface preparation: Silicon wafers (Si-Mat Silicon Materials Landsberg/ Deutschland) were coated with $\mathrm{TiO}_{2}(15 / 20 \mathrm{~nm})$ by magnetron sputtering (PSI Villingen, Switzerland). Metal oxide coated wafers were subsequently sawn into $1 \mathrm{~cm} \times 1 \mathrm{~cm}$ pieces. Prior to polymer modification, $\mathrm{TiO}_{2}$-coated silicon wafers were sonicated in toluene twice for $10 \mathrm{~min}$ followed by two times 7 minutes sonication in 2-propanol and dried under a stream of nitrogen and finally exposed to $\mathrm{O}_{2}$ plasma (Harrick Scientific Corporation, Ossining, NY) for $3 \mathrm{~min}$ to remove adventitious contamination from the surface.

Ellipsometry (VASE): The adlayer thickness on $\mathrm{TiO}_{2}$ wafers was measured by $\mathrm{M}-2000 \mathrm{~F}^{\mathrm{TM}}$ Variable angle spectroscopic ellipsometry (J. A. Woollam Co., Inc.) at $65^{\circ} \mathrm{C}, 70^{\circ} \mathrm{C}$ and $75^{\circ} \mathrm{C}$ using wavelengths from 370 to $1000 \mathrm{~nm}$. VASE spectra were fit with multilayer modes using a custom analysis software (WVASE 32).

X-ray Photoelectron Spectroscopy (XPS): XPS data were acquired on a SIGMA probe thermo XPS system spectrophotometer. The instrument was equipped with a multichannel detector and an Alpha 110 hemispherical analyzer. All spectra were acquired at $300 \mathrm{~W}$ with an $\mathrm{Al} \mathrm{K} \alpha \mathrm{X}$-ray source $(1486.6 \mathrm{eV})$ with large area spotsize. High-resolution spectra (C 1s, N 1s) were recorded with $0.1 \mathrm{eV}$ step size and $25 \mathrm{eV}$ pass energy. Recorded spectra were referenced to the aliphatic hydrocarbon $\mathrm{C} 1 \mathrm{~s}$ 
signal at $285.0 \mathrm{eV}$. Data were analyzed using the program CasaXPS [Version 2.3.5 www.casaxps.com]. The signals were fitted using Gaussian-Lorentzian functions and Marquardt-Levenberg optimization algorithm following Shirley iterative background subtraction.

Preparation of trimethylammonium dopamine 5: Compound 4 (44 mg, $0.14 \mathrm{mmol}$, 1.0 eq) was dissolved in $\mathrm{CH}_{2} \mathrm{Cl}_{2} / \mathrm{MeOH}(2 / 1)(1 \mathrm{~mL})$. MeI $(44 \mu \mathrm{L}, 0.71 \mathrm{mmol}, 5.0$ eq. was added and the solution stirred at RT for 6 hours under $\mathrm{N}_{2}$. The solvent was removed under reduced pressure to give $62 \mathrm{mg}(0.14 \mathrm{mmol}, 97 \%)$ of the title compound 5 . ${ }^{1} \mathrm{H}$ NMR (CD $\mathrm{OD}, 400 \mathrm{Mhz}) 1.36-1.39(\mathrm{~s}, 9 \mathrm{H}$, Boc-rotamers), 2.61-2.74 (m, 2H) $3.17(\mathrm{~s}$ 9H), $3.49(\mathrm{~m}, 2 \mathrm{H}), 4.20-4.23(\mathrm{~m}, 1 \mathrm{H}), 6.59-6.61(\mathrm{~m}, 1 \mathrm{H}), 6.72-6.74(\mathrm{~m}, 2 \mathrm{H}) ;{ }^{13} \mathrm{C}-\mathrm{NMR}$ $\left(\mathrm{CD}_{3} \mathrm{OD}, 100 \mathrm{MHz}\right) 27.5,27.6$ (Boc rotamers), 40.7, 48.4, 54.8, 73.8, 79.5, 115.6, 116.8 123.2, 132.0, 144.6, 145.8, 155.6; HRMS calcd for $\mathrm{C}_{17} \mathrm{H}_{29} \mathrm{~N}_{2} \mathrm{O}_{4}[\mathrm{M}+\mathrm{H}]^{+}: 325.2122$; found 325.2127 .

Preparation of compound 6: Compound 4 (250 mg, $0.81 \mathrm{mmol}, 1.0$ eq.) was suspended in $\mathrm{CH}_{2} \mathrm{Cl}_{2}(4 \mathrm{ml})$, cooled to $0^{\circ} \mathrm{C}$ under $\mathrm{N}_{2}$. TFA $(2 \mathrm{~mL})$ was added dropwise and the solution stirred at $0^{\circ} \mathrm{C}$ for 1 hour and at RT for 1 hour. The reaction mixture was then concentrated, redissolved in toluene $(1 \mathrm{~mL})$, concentrated and dried under high pressure. The residue was dissolved in $\mathrm{CH}_{2} \mathrm{Cl}_{2}(10 \mathrm{~mL}), \mathrm{Et}_{3} \mathrm{~N}(450 \mu \mathrm{L}, 4.0$ eq. $)$ and HOBt $(130 \mathrm{mg}, 1.2 \mathrm{eq}$.) were added and the solution stirred for 5 minutes at RT. $\mathrm{EDC} \cdot \mathrm{HCl}(165 \mathrm{mg}, 1.2 \mathrm{eq}$ ) and a solution of BOC-L-DOPA (259 mg, $1.1 \mathrm{eq}$.) in $\mathrm{CH}_{2} \mathrm{Cl}_{2}(3 \mathrm{~mL})$ were added. The solution was stirred at $0^{\circ} \mathrm{C}$ for 1 hour and at RT for 18 hours under $\mathrm{N}_{2}$ under the exclusion of light. The reaction mixture was concentrated, diluted in $\mathrm{Et}_{2} \mathrm{O}$ and washed with $1 \mathrm{M} \mathrm{HCl}(2 \times 10 \mathrm{~mL})$, saturated $\mathrm{NaHCO}_{3}(2 \times 10 \mathrm{~mL})$ and brine $(10 \mathrm{~mL})$. The organic layer was dried $\left(\mathrm{MgSO}_{4}\right)$, concentrated and the residue purified by chromatography on $\mathrm{SiO}_{2}\left(\mathrm{CH}_{2} \mathrm{Cl}_{2} / \mathrm{MeOH}(8: 1)\right)$ to give $287 \mathrm{mg}(0.63 \mathrm{mmol}$, $54 \%$ ) of the title compound.

Preparation of mPEG-SPA: mPEG-propionic acid $(150 \mathrm{mg}, 30 \mu \mathrm{mol}, 1.0$ eq. $)$ was dissolved in $\mathrm{CHCl}_{3}(3 \mathrm{~mL})$ at $0^{\circ} \mathrm{C}$ under $\mathrm{N}_{2}$. DCC $(7 \mathrm{mg}, 33 \mu \mathrm{mol}, 1.1$ eq. $)$ was added and the solution stirred for 15 minutes at $0^{\circ} \mathrm{C}$. NHS ( $4 \mathrm{mg}, 33 \mu \mathrm{mol}, 1.1 \mathrm{eq}$.) was added and the solution stirred for 1 hour at $0^{\circ} \mathrm{C}$ and for 14 hours at RT under $\mathrm{N}_{2}$. The reaction mixture was kept at $4^{\circ} \mathrm{C}$ for 4 hours and filtered. The solvent was removed and the residue was dissolved in $\mathrm{Et}_{2} \mathrm{O}(30 \mathrm{~mL})$ and stored at $4^{\circ} \mathrm{C}$ for 1 hour. Filtration gave 146 $\mathrm{mg}(29 \mu \mathrm{mol}, 97 \%)$ of the title compound, which was used without further purification.

Preparation of polymer 7: Compound 4 (14 mg, $30 \mu \mathrm{mol}, 3.0$ eq.) was dissolved in $\mathrm{CH}_{2} \mathrm{Cl}_{2}(1 \mathrm{~mL})$, cooled at $0^{\circ} \mathrm{C}$ under $\mathrm{N}_{2}$, and TFA $(1 \mathrm{~mL})$ was added dropwise. The solution stirred for 1 hour at $0^{\circ} \mathrm{C}$ and for 1 hour at RT. The solvent was removed and the residue was dissolved in toluene and concentrated. The residue was dissolved in $\mathrm{CH}_{2} \mathrm{Cl}_{2} / \mathrm{DMF}(1 / 1)(1 \mathrm{~mL})$ under $\mathrm{N}_{2}$. N-methylmorpholine $(50 \mu \mathrm{L})$ was added dropwise and the solution stirred at RT for 15 minutes. mPEG-SPA $(50 \mathrm{mg}, 10 \mu \mathrm{mol}, 1.0$ eq.) was added an the solution stirred for 14 hours at RT under $\mathrm{N}_{2}$. The solution was filtrated, diluted in $\mathrm{Et}_{2} \mathrm{O}(30 \mathrm{~mL})$ and stored at $4^{\circ} \mathrm{C}$ for 4 hours. Filtration and purification by chromatography on Sephadex LH-20 (MeOH) gave $22 \mathrm{mg}(4 \mu \mathrm{mol}, 44 \%)$ of the title compound.

Preparation of polymer 8: Compound 5 ( $9 \mathrm{mg}, 30 \mu \mathrm{mol}, 3.0$ eq.) was dissolved in $\mathrm{CH}_{2} \mathrm{Cl}_{2}(1 \mathrm{~mL})$, cooled at $0^{\circ} \mathrm{C}$ under $\mathrm{N}_{2}$, and TFA $(1 \mathrm{~mL})$ was added dropwise. The solution stirred for 1 hour at $0^{\circ} \mathrm{C}$ and for 1 hour at RT. The solvent was removed and the residue was dissolved in toluene and concentrated. The residue was dissolved in $\mathrm{CH}_{2} \mathrm{Cl}_{2} / \mathrm{DMF}(1 / 1)(1 \mathrm{~mL})$ under $\mathrm{N}_{2}$. N-methylmorpholine $(50 \mu \mathrm{L})$ was added dropwise and the solution stirred at RT for 15 minutes. mPEG-SPA (50 mg, $10 \mu \mathrm{mol}, 1.0$ eq.) was added an the solution stirred for 14 hours at RT under $\mathrm{N}_{2}$. The solution was filtrated, diluted in $\mathrm{Et}_{2} \mathrm{O}(30 \mathrm{~mL})$ and stored at $4^{\circ} \mathrm{C}$ for 4 hours. Filtration and purification by chromatography on Sephadex LH-20 (MeOH) gave $32 \mathrm{mg}(6 \mu \mathrm{mol}, 64 \%)$ of the title compound.

Preparation of polymer 9: Compound 6 ( $15 \mathrm{mg}, 30 \mu \mathrm{mol}, 3.0$ eq.) was dissolved in $\mathrm{CH}_{2} \mathrm{Cl}_{2}(1 \mathrm{~mL})$, cooled at $0^{\circ} \mathrm{C}$ under $\mathrm{N}_{2}$, and TFA $(1 \mathrm{~mL})$ was added dropwise. The solution stirred for 1 hour at $0^{\circ} \mathrm{C}$ and for 1 hour at RT. The solvent was removed and the residue was dissolved in toluene and concentrated. The residue was dissolved in $\mathrm{CH}_{2} \mathrm{Cl}_{2} / \mathrm{DMF}(1 / 1)(1 \mathrm{~mL})$ under $\mathrm{N}_{2}$. N-methylmorpholine $(50 \mu \mathrm{L})$ was added dropwise and the solution stirred at RT for 15 minutes. mPEG-SPA (50 mg, $10 \mu \mathrm{mol}, 1.0$ eq.) was added an the solution stirred for 14 hours at RT under $\mathrm{N}_{2}$. The solution was filtrated, diluted in $\mathrm{Et}_{2} \mathrm{O}(30 \mathrm{~mL})$ and storred at $4^{\circ} \mathrm{C}$ for 4 hours. Filtration and purification by chromatography on Sephadex LH-20 (MeOH) gave $30 \mathrm{mg}(5 \mu \mathrm{mol}, 60 \%)$ of the title compound.

Preparation of polymer 11: Boc-L-Glu (10) $(300 \mathrm{mg}, 1.2 \mathrm{mmol}, 1.0 \mathrm{eq})$ was dissolved in $\mathrm{CHCl}_{3}(3 \mathrm{~mL})$ and cooled to $0^{\circ} \mathrm{C}$ (ice-bath). $\mathrm{NEt}_{3}(750 \mu \mathrm{L}, 5.3 \mathrm{mmol}, 4.0 \mathrm{eq}), \mathrm{HOB}$ (360 mg, $2.4 \mathrm{mmol}, 2.00 \mathrm{eq})$, EDC hydrochloride $(510 \mathrm{mg}, 2.7 \mathrm{mmol}, 2.2 \mathrm{eq})$ and dopamine hydrochloride $(690 \mathrm{mg}, 3.6 \mathrm{mmol}, 3.00 \mathrm{eq})$ were sequentially added. The reaction mixture stirred at $0^{\circ} \mathrm{C}$ for 1 hour and at $\mathrm{RT}$ for $16 \mathrm{~h}$. The mixture was diluted with $\mathrm{CHCl}_{3}(10 \mathrm{~mL})$, washed with $1 \mathrm{~N} \mathrm{HCl}(2 \times 10 \mathrm{~mL})$, sat. $\mathrm{NaHCO}_{3}(2 \times 10 \mathrm{~mL})$ and brine $(10 \mathrm{~mL})$. The organic layer was dried over $\mathrm{Na}_{2} \mathrm{SO}_{4}$, filtered and concentrated. The residue was purified by chromatography on $\mathrm{SiO}_{2}\left(\mathrm{CH}_{2} \mathrm{Cl}_{2} / \mathrm{MeOH} 9 / 1\right)$ to give $477 \mathrm{mg}$
(0.92 mmol, $76 \%)$ of $(S)$-tert-butyl 1,5-bis(3,4-dihydroxyphenethylamino)-1,5dioxopentan-2-ylcarbamate. ${ }^{1} \mathrm{H}-\mathrm{NMR}\left(400 \mathrm{MHz}, \mathrm{CDCl}_{3}\right)$ 1.41-1.44 (s, 9H, Boc rotamers), $1.68(\mathrm{~m}, 2 \mathrm{H}), 1.82(\mathrm{~m}, 2 \mathrm{H}), 2.03(\mathrm{~m}, 2 \mathrm{H}), 2.30(\mathrm{~m}, 2 \mathrm{H}), 2.66(\mathrm{~m}, 2 \mathrm{H}), 4.20$ $(\mathrm{m}, 1 \mathrm{H}), 6.56-6.61(\mathrm{~m}, 2 \mathrm{H}), 6.63(\mathrm{~d}, J=0.96 \mathrm{~Hz}, 2 \mathrm{H}), 6.79(\mathrm{~d}, J=8.32 \mathrm{~Hz}, 2 \mathrm{H}) \cdot{ }^{13} \mathrm{C}-$ NMR $\left(\mathrm{CDCl}_{3}, 100 \mathrm{MHz}\right) 27.2,28.2,29.6,34.6,34.8,40.4,41.1,51.8,80.4,115.3$, $115.5,115.7,115.8,120.5,120.6,130.5,130.7,143.0,143.1,144.0,144.1,155.9,171.9$ 173.9 IR $3402 m, 3010 m, 1780 s, 1580 s, 1273 s, 1151 s$. (S)-tert-butyl 1,5-bis(3,4dihydroxyphenethylamino)-1,5-dioxopentan-2-ylcarbamate (15 mg, $30 \mu \mathrm{mol}, 3.0$ eq.) was dissolved in $\mathrm{CH}_{2} \mathrm{Cl}_{2}(1 \mathrm{~mL})$, cooled at $0^{\circ} \mathrm{C}$ under $\mathrm{N}_{2}$, and $\mathrm{CF}_{3} \mathrm{CO}_{2} \mathrm{H}(1 \mathrm{~mL})$ was added dropwise. The solution stirred for 1 hour at $0^{\circ} \mathrm{C}$ and for 1 hour at RT. The solvent was removed and the residue was dissolved in toluene and concentrated. The residue was dissolved in $\mathrm{CH}_{2} \mathrm{Cl}_{2} / \mathrm{DMF}(1 / 1)(1 \mathrm{~mL})$ under $\mathrm{N}_{2} . N$-methylmorpholine $(50 \mu \mathrm{L})$ was added dropwise and the solution stirred at RT for 15 minutes. mPEG-SPA (50 mg, 10 $\mu \mathrm{mol}, 1.0$ eq.) was added an the solution stirred for 14 hours at RT under $\mathrm{N}_{2}$. The solution was filtrated, diluted in $\mathrm{Et}_{2} \mathrm{O}(30 \mathrm{~mL})$ and stored at $4^{\circ} \mathrm{C}$ for 4 hours. Filtration and purification by chromatography on Sephadex LH-20 (MeOH) gave $30 \mathrm{mg}(5 \mu \mathrm{mol}$, $56 \%$ ) of the title compound 11 .

\section{Acknowledgements}

K. G. is a European Young Investigator (EURYI). We thank the SNF for support of this work (200021-115918/1)

[1] G. M. Dickinson, A. L. Bisno, International Journal of Artificial Organs 1993 16, 749-754.

[2] a) J. W. Costerton, Z. Lewandowski, D. E. Caldwell, D. R. Korber, H. M. Lappin-Scott, Ann. Rev. Microbiol. 1995, 49, 711-745; b) L. Hall-Stoodley, J. W. Costerton, P. Stoodley, Nat. Rev. Microbiol. 2004, 2, 95-108.

[3] M. T. Madigan, J. M. Martinko, J. Parker, Brock Biology of Microorganisms, $8^{\text {th }}$ rev. ed., Prentice Hall, 1997.

[4] a) J. M. Higashi, I. W. Wang, D. M. Shlaes, J. M. Anderson, R. E. Marchant, J. Biomed. Mater. Res. 1998, 39, 341-350; b) K. M. Cunnion, J. C. Lee, M. M Frank, Infect. Immun. 2001, 69, 6796-6803.

[5] a) P. Kingshott, H. J. Griesser, Curr. Opin. Solid State Mater. Sci. 1999, 4, $403-$ 412; b) D. M. Yebra, S. Kiil, K. Dam-Johansen, Prog. Org. Coat. 2004, 50, 75 104 .

[6] a) J. H. Lee, J. Kopecek, J, D. Andrade, J. Biomed. Mat. Res. 1989, 23, 351-368; b) K. L. Prime, G. M. Whitesides, Science 1991, 252, 1164-1167; c) N. P. Desai, J. A. Hubbell, Biomaterials 1991, 12, 144-153; d) Z. Yang, J. A. Galloway, H. $\mathrm{Yu}$, Langmuir 1999, 15, 8405-8411.

[7] C. Siegers, M. Biesalski, R. Haag, Chem. Eur. J. 2004, 10, 2831-2838.

[8] L. H. Marsh, M. Coke, P. W. Dettmar, R. J. Ewen, M. Havler, T. G. Nevell, J. D. Smart, J. R. Smith, B. Timmins, J. Tsibouklis, C. Alexander, J. Biomed. Mater. Res. 2002, 61, 641-652.

[9] J. H. Lee, Y. M. Ju, D. M. Kim, Biomaterials 2000, 21, 683-691.

[10] A. R. Statz, R. J. Meagher, A. E. Barron, P. B. Messersmith, J. Am. Chem. Soc. 2005, 127, 7972-7973.

[11] R. Konradi, B. Pidhatika, A. Muhlebach, M. Textor, Langmuir 2008, 24, 613616.

[12] S. Pasche, S. M. De Paul, J. Vörös, N. D. Spencer, M. Textor, Langmuir 2003, 19, 9216-9225.

[13] Z. Yang, J. A. Galloway, H. Yu, Langmuir 1999, 15, 8405-8411.

[14] J. C. Love, L. A. Estroff, J. K. Kriebel, R. G. Nuzzo, G. M. Whitesides, Chem. Rev 2005, 105, 1103-1169.

[15] a) J. H. Waite, M. L. Tanzer, Science 1981, 212, 1038-1040; b) C. R. Rice, M. D. Ward, M. K. Nazeeruddin, M. Grätzel, New J. Chem. 2000, 24, 651-652; c) J. L. Dalsin, B. H. Hu, B. P. Lee, P. B. Messersmith, J. Am. Chem. Soc. 2003, 125 , 4253-4258; d) X. Fan, L. Lin, J. L. Dalsin, P. B. Messersmith, J. Am. Chem. Soc 2005, 127, 15843-15847; e) H. Lee, N. F. Scherer, P. B. Messersmith, Proc. Nat. Acad. Sci. U.S.A. 2006, 103, 12999-13003; f) J. L. Dalsin, P. B. Messersmith, Mater. Today 2005, 8, 38; g) J. L. Dalsin, L. Lin, S. Tosatti, J. Vörös, M. Textor, P. B. Messersmith, Langmuir 2005, 21, 640-646; h) H. Lee, S. M. Dellatore, W. M. Miller, P. B. Messersmith, Science 2007, 318, 426-430.

[16] a) T. J. Deming, Curr. Opin. Chem. Biol. 1999, 3, 100-105; b) H. G. Silverman, F. F. Roberto, Mar. Biotechnol. 2007, 9, 661-681.

[17] a) S. Zürcher, D. Wäckerlin, Y. Bethuel, B. Malisova, M. Textor, S. Tosatti, K. Gademann, J. Am. Chem. Soc. 2006, 128, 1064-1065; b) J.-Y. Wach, S. Bonazzi, 
K. Gademann, Angew. Chem. 2008, 120, doi:10.1002/ange.200801570, Angew. Chem. Int. Ed. 2008, 47, doi:10.1002/anie.200801570.

[18] a) K. Gademann, Y. Bethuel, Org. Lett. 2004, 6, 4707-4710; b) K. Gademann, Y. Bethuel, Angew. Chem. 2004, 116, 3389-3391; Angew. Chem., Int. Ed. 2004, 43, 3327-3329; c) K. Gademann, Y. Bethuel, H. H. Locher, C. Hubschwerlen, J. Org. Chem. 2007, 72, 8361-8370; d) K. Gademann, ChemBioChem 2005, 6, 913-919.

[19] a) P. Tengvall, I. Lunstrom, Clin. Mater. 1992, 9, 115-134; b) X. Liu, P. K. Chu, C. Ding, Mater. Sci. Eng. R 2004, 47, 49-121.

Received: ((will be filled in by the editorial staff))

Revised: ((will be filled in by the editorial staff)) Published online: ((will be filled in by the editorial staff)) 
Protein-Resistant Surfaces

Jean-Yves Wach, Barbora Malisova, Simone Bonazzi, Samuele Tosatti,

Marcus Textor, Stefan Zürcher and

Karl Gademann*

Protein-Resistant Surfaces through

Mild Dopamine Surface

Functionalization
Protein-resistant surfaces can be<smiles>CCC(C)(C)OCC(C)CC(=O)NC(CCC(=O)NCCc1ccc(O)c(O)c1)C(=O)NCCc1ccc(O)c(O)c1</smiles>
generated though mild dip-and-rinse functionalization of $\mathrm{TiO}_{2}$ surfaces with dopamine derived PEG polymers. 